\title{
sciendo
}

Current Issues in Pharmacy and Medical Sciences

Formerly ANNALES UNIVERSITATIS MARIAE CURIE-SKLODOWSKA, SECTIO DDD, PHARMACIA

journal homepage: http://www.curipms.umlub.pl/

\section{A massive malignant phyllodes tumor - case study}

\author{
Barbara Madej-CzerwonkA*
}

Department of Human Anatomy, Medical University of Lublin, Poland

\begin{tabular}{|c|c|}
\hline ARTICLE INFO & ABSTRACT \\
\hline $\begin{array}{l}\text { Received } 20 \text { December } 2020 \\
\text { Accepted } 31 \text { December } 2020\end{array}$ & $\begin{array}{l}\text { The paper aims to introduce the case of an extensive breast malignancy - phyllodes } \\
\text { tumor. This type of breast neoplasm is relatively rare. Indeed, it accounts for only } 0.3-1 \%\end{array}$ \\
\hline $\begin{array}{l}\text { Keywords: } \\
\text { phyllodes tumour, } \\
\text { breast cancer, } \\
\text { breast, } \\
\text { malignancy, } \\
\text { neoplasm. }\end{array}$ & $\begin{array}{l}\text { of all breast malignant tumours. In the paper, patient, disease, and treatment methods } \\
\text { were described and evaluated. The efficacy of surgical treatment and adjuvant therapy } \\
\text { (radiotherapy and chemotherapy) was assessed based on literature data. The authors } \\
\text { concluded that late diagnosis of phyllodes tumor causes the necessity of mastectomy and } \\
\text { radiotherapy and aggravates the prognosis. }\end{array}$ \\
\hline
\end{tabular}

\section{INTRODUCTION}

Breast neoplasms are currently the most common cancer diagnosed in female patients - and the incidence rate is increasing dramatically. There are 18500 new cases of breast cancer each year in Poland. The phyllodes tumour is a relatively rare type of neoplasm and it accounts for only $0.3-1 \%$ of all breast malignant tumours, on average $[1,2]$. Histologically, it forms typically large, fast-growing masses that originate from the periductal stromal cells of the breast. Clinically characterized by rapid and expanding growth and ability of creating distant metastases [3], it was described for the first time in 1838 by Johannes Muller [4].

Phyllodes tumours may present different grades of malignancy. Because of that fact, in 2003, the WHO developed an international histological classification that divides these tumours into three subtypes: benign, borderline and malignant [3]. Qualification for a particular type is based on histologic parameters: stromal cell atypia, interstitial cell hyperplasia, mitotic activity and infiltration at the tumour's edge. It is estimated that the incidence of each of the types are: benign $-58 \%$, borderline $-12 \%$, malignant $-30 \%$ [5] The clinical course of malignant phyllodes tumour is similar to sarcoma, demonstrating local recurrence at up to $40 \%$ of all cases and can develop distant blood-borne metastases (most common are the lungs, bones, soft tissues and pleura). Progression through lymph vessels to lymph nodes is the least common type of metastases [6].

The type of treatment depends on the type of the neoplasm and might include partial breast excision, simple mastectomy or modified radical mastectomy. First-choice treatment is total excision of the lesion, mastectomy if the subtype is malignant. In cases where lymph nodes are

\footnotetext{
* Corresponding author

e-mail: barbara.madej-czerwonka@umlub.pl
}

involved, lymphadenectomy is necessary as well. Due to high local recurrence, which is a negative prognostic factor, total tumour excision is essential [7,8]. Risk factors of local recurrence are still not fully specified. It is certain though, that the area of total excision, grade of histological malignancy, atypia and mitotic activity are amongst these factors [9-12]. The effectiveness of postoperative, adjuvant therapy is unclear, there is no significant, statistical influence of adjuvant therapy with doxorubicin and dacarbazine on survival rate [13]. Postoperative radiotherapy, however, proved to be effective in decreasing chances of recurrence, regarding highly malignant phyllodes tumours and tumours of greater diameter $(>2 \mathrm{~cm})[14,15]$.

\section{CASE STUDY}

A female 44 year-old patient showed up at the oncological surgery clinic suffering from a massive tumour located in her right breast. According to the patient's medical history, the tumour appeared 14 months before the visit. She was able to feel the protrusion: $2-3 \mathrm{~cm}$ in diameter and located at 12:00. Two to three months after, another tumour was palpable $-2 \mathrm{~cm}$ in diameter and located at 6:00 of the same breast - patient was not sure whether the lesion was a new one, or an expansion of the one discovered earlier. The patient did not seek medical attention, hoping that the alterations would reverse on their own.

The following next five months showed that the tumour was growing rapidly, violet skin discolouration became visible in the area, and the surface became uneven (Fig. 1). The malignancy caused a significant bulge in the upper right quadrant, nevertheless, both breasts were symmetrical at the time. In the subsequent four months, the tumour grew 
even further, causing significant asymmetry and erratic skin surfaces (Fig. 2). Three months later, convinced by

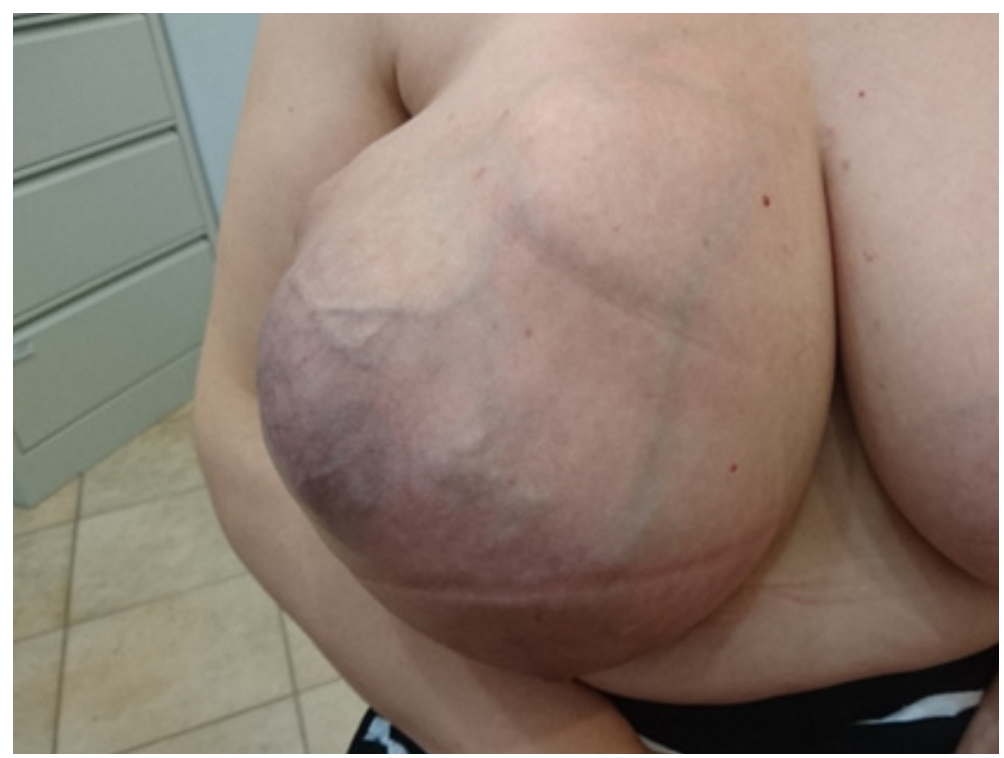

Figure 1. Massive malignant phyllodes tumour of the right breast.

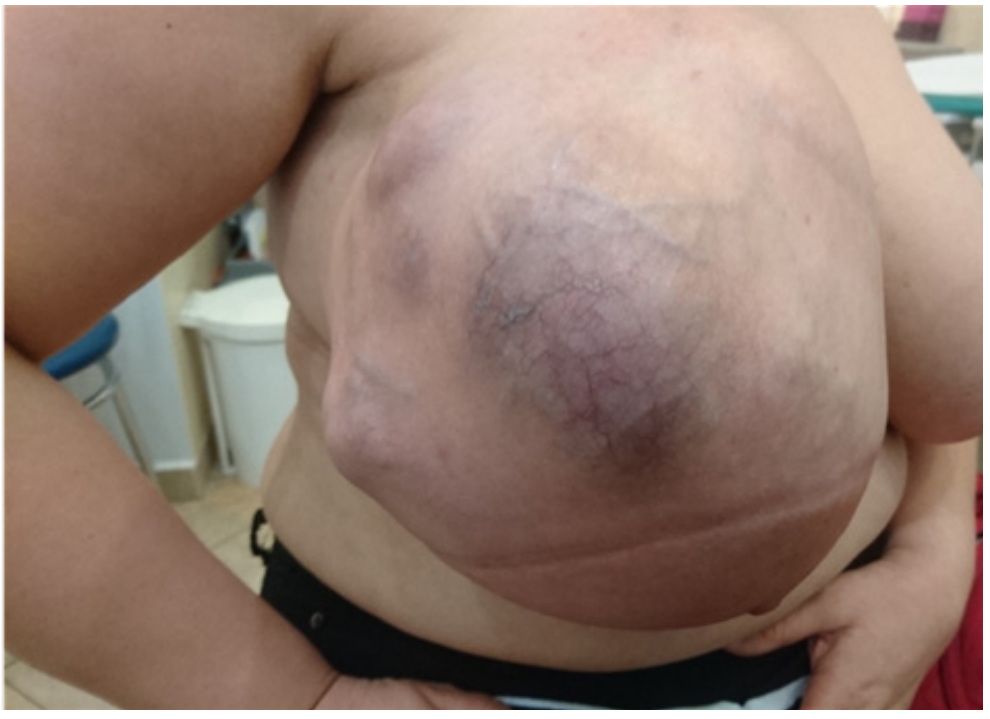

Figure 2. Massive malignant phyllodes tumour of the right breast (lateral view) confirmed borderline phyllodes tumour mammae dextrae, mitotic index: 5/10 high-power fields (HPF).

$\mathrm{CT}$ results showed: massive right breast tumour; polycyclic outlines $17 \times 18 \times 20 \mathrm{~cm}$. After administering intravenous contrast agent, the tumour image was fortified and revealed that it bordered the chest muscles, but did not infiltrate them. Axillary lymph nodes on the left-hand side were not enlarged - The CT scan displayed a dominance of longitudinal dimension and $8 \mathrm{~mm}$ in short axis. There were no focal lesions to be found in the left mammary gland. Left axillary and both subclavicular lymph nodes were also of physiological size. No pathological changes were found in other tissues, including lung, liver, bones, pancreas, spleen and kidneys.

Left breast mammography showed no pathological changes - categorised as BIRADS 2 . Neither morphology nor biochemistry of plasma showed any aberrations. Based on clinical history and additional examinations, the patient was qualified for simple mastectomy of the right mammary gland. Removal of the right breast, with a fraction of pectoralis major muscle was carried out under general anaesthesia. Excised tissue amassed to 4.1 kilograms. Full histopathological examination of the tissue was carried out. Postoperative status of the patient was good, no complications were recorded. Postoperative examination confirmed that the lesion was indeed a phyllodes tumour. The patient was qualified for adjuvant radiotherapy.

\section{DISCUSSION}

Due to the rarity of the phyllodes tumor, current treatment recommendations are mainly based on retrospective studies. The primary method of treatment of phyllodes tumor is surgical treatment [16]. The preferred treatment is a tumorectomy with a margin greater than $1 \mathrm{~cm}$. For a tumor of large size where margin her mother, the patient sought medical attention.

First medical examination revealed that the whole right breast was twice the size of the other one and filled with tumours. Neither axillary nor supraclavicular lymph nodes were enlarged. There were no tumours present in the left breast, and the patient did not suffer from any other symptoms. The patient was urgently admitted to the Breast Unit of Stefan Cardinal Wyszynski District Hospital in Lublin for further tumour examination. Initial diagnosis was made - malignant phyllodes tumour. The following day, she was admitted to the hospital. Chest, abdomen and pelvic CT were carried out, in order to determine the grade of the tumour and the presence of any metastases on lymph nodes or solid organs. Mammography of the left breast and diagnostic biopsy of the right breast were performed. Right breast mammography was held up to prevent too much pressure on the tumour. Histopathological examination preservation is impossible, a simple mastectomy is recommended. In the case of clinically unchanged lymph nodes, there is no indication for axillary lymphadenectomy. Best adjuvant therapy is under discussion. According to current recommendations, chemotherapy does not affect overall survival and does not reduce the risk of local relapse. In the case of local relapse, the gold standard of treatment is surgery by local excision [17].

The risk factor of local relapse in this patient definitely was the size of the tumor. According to the literature, the tumor being of small size is a factor that significantly improves the prognosis. The average size of the tumor ranges from 4 to $8 \mathrm{~cm}$. There are also cases of tumors $40 \mathrm{~cm}$ [18]. In the study of Belkacémi, Yazid, et al. tumor below 3 $\mathrm{cm}$ was a favorable prognostic factor of local control [19]. Kapiris et al. add that the tumor size and free surgical margin were found to be the main risk factors of local relapse. For a tumor with a high malignancy and a large tumor size, a 
mastectomy is recommended [20]. Other prognosis factors are the age and mitotic activity of neoplasm cells [21]. In the study published by Chen et al. age, type of surgery treatment, large margin and mitotic activity were correlated with local relapse [22].

One of the main problems in breast cancer diagnosis is the fact that it is done not soon enough. The main reason is low attendance at prophylactic screenings. Mammography screening effectiveness in Poland is at the level of $37 \%$, whereas in western Europe, it is at the level of $47 \%-70 \%$.

Effective prevention is extremely important regarding phyllodes tumours for they show time-dependent tendency to change their stage to a more malignant subtype. The consequence of this fact is radical deterioration of the prognosis.

Despite numerous clinical studies on the use of adjuvant therapy, surgical treatment is still decisive in final results of the therapy.

\section{CONCLUSIONS}

This case shows that low health awareness, fear and emotional limitations of patients can affect the treatment. Moreover, patient negligence for early diagnostics may cause long-term complications, such as relapse or negative consequences of radiotherapy. With this patient, due to delay of the diagnosis, extensive mastectomy and invasive radiotherapy was necessary, whereas in the early stages of the disease, the patient could have preserved her breast and be subjected to observation alone.

\section{ORCID iDs}

Barbara Madej-Czerwonka

(D)https://orcid.org/0000-0002-2165-9651

\section{REFERNCES}

1. Guerrero MA, Ballard BR, Grau AM. Malignant phyllodes tumor of the breast: review of the literature and case report of stromal overgrowth. Surg Oncol. 2003;12.1:27-37.

2. Zhou ZR, Wang CC, Yang ZZ, Yu XL, Guo XM. Phyllodes tumors of the breast: diagnosis, treatment and prognostic factors related to recurrence. J Thorac Dis. 2016;8(11):3361.

3. Tavassoli FA, Deville P. Pathology and genetics of tumours of the breast and female genital organs. WHO Classification of Tumours series - volume IV. Lyon, France: IARC Press; 2003.

4. Muller J. Über den feinern Bau und die Formen der krankhaften Geschwülste: in zwei Lieferungen. Berlin: G Reimer. 1838:54-7.
5. Moffat CJ, Pinder SE, Dixon AR, Elston CW, Blamey RW, Ellis IO. Phyllodes tumour of the breast: a clinicopathological review of the thirty-two cases. Histopathology. 1995,27.3:205-18.

6. Parker SJ, Harries SA. Phyllodes tumours. Postgrad Med J. 2001;77:428-35.

7. Ramakant P, Chakravarthy S, Cherian JA, Abraham DT, Paul MJ. Challenges in management of phyllodes tumors of the breast: a retrospective analysis of 150 patients. Indian J Cancer. 2013;50(4):345-8.

8. Macdonald OK, Lee CM, Tward JD, Chappel CD, Gaffney DK. Malignant phyllodes tumor of the female breast. Cancer. 2006;107(9):2127-33.

9. Hines JR, Murad TM, Beal JM. Prognostic indicators in cystosarcoma phylloides. Am J Surg. 1987;153(3):276-80.

10. Wang Y. Development of cancer diagnostics -from biomarkers to clinical tests. Transl Cancer Res. 2015;4(3):270-9.

11. Sotheran W, Domjan J, Jeffrey M, Wise MH, Perry PM. Phyllodes tumours of the breast-a retrospective study from 1982-2000 of 50 cases in Portsmouth. Ann R Coll Surg Engl. 2005;87(4):339-44.

12. Haberer S, Laé M, Seegers V, Pierga JY, Salmon R, Kirova YM, et al. Management of malignant phyllodes tumors of the breast: the experience of the Institut Curie. Cancer Radiother. 2009;13(4):305-12.

13. Morales-Vásquez F, Gonzalez-Angulo AM, Broglio K, Lopez-Basave HN, Gallardo D, Hortobagyi GN, et al. Adjuvant chemotherapy with doxorubicin and dacarbazine has no effect in recurrencefree survival of malignant phyllodes tumors of the breast. Breast $\mathrm{J}$. 2007;13(6):551-6.

14. Belkacémi Y, Bousquet G, Marsiglia H, Ray-Coquard I, Magné N, Malard Y. et al. Phyllodes tumor of the breast. Int J Radiat Oncol Biol Phys. 2008;70(2):492-500.

15. Pandey M, Mathew A, Abraham EK, Rajan B. Primary sarcoma of the breast. J Surg Oncol. 2004;87(3):121-5.

16. Gnerlich JL, Williams RT, Yao K, Jaskowiak N, Kulkarni SA. Utilization of radiotherapy for malignant phyllodes tumors: analysis of the National Cancer Data Base, 1998-2009. Ann Surg Oncol. 2014; 21(4):1222-30.

17. Nowecki Z, Jeziorski A. Chirurgiczne leczenie zmian nowotworowych piersi: II konsensus PTChO. Gdańsk: Via Medica; 2019:63-64.

18. Guerrero, Marlon A., Billy R. Ballard, and Ana M. Grau. Malignant phyllodes tumor of the breast: review of the literature and case report of stromal overgrowth. Surg Oncol. 2003;12(1):27-37.

19. Belkacémi Y, Bousquet G, Marsiglia H, Ray-Coquard I, Magne N, Malard Y, et al. Phyllodes tumor of the breast. Int J Radiat Oncol. 2008;70(2):492-500.

20. Kapiris I, Nasiri N, Healy V, Gui GPH. Outcome and predictive factors of local recurrence and distant metastases following primary surgical treatment of high-grade malignant phyllodes tumours of the breast. Eur J Surg Oncol. 2001;27(8):723-30.

21. Khosravi-Shahi P. Management of non metastatic phyllodes tumors of the breast: review of the literature. Surg Oncol. 2011; 20(4):e143-e148.

22. Chen WH, Cheng SP, Tzen CY, Yang TL, Jeng KS, Liu CL, Liu TP. Surgical treatment of phyllodes tumors of the breast: retrospective review of 172 cases. J Surg Oncol. 2005;91(3):185-94. 